\title{
Pelvic renal ectopia, an incidental finding
}

\author{
Farah Aslam
}

Lewisham and Greenwich NHS Trust, London, UK

\section{Correspondence to}

Dr Farah Aslam,

f.aslam@nhs.net

Accepted 14 February 2017

\section{DESCRIPTION}

A woman aged 33 years presented with a 2 -week history of non-traumatic back pain, progressive bilateral lower limb weakness with paraesthesia and urinary incontinence. She had a background of recurrent urinary tract infection and hypertension.

Clinical examination revealed reduced power bilaterally (grade 3/5) and reduced reflexes but normal tone. She was unable to walk. Abdominal examination was unremarkable and per rectal examination was normal with good anal tone. She was apyrexial with a blood pressure of 132/ $86 \mathrm{~mm} \mathrm{Hg}$ and heart rate of $84 \mathrm{bpm}$. Admission blood tests (including FBC, CRP, U\&E, bone profile, magnesium, B12 and folate) were normal. Urine dipstick was also normal.

An urgent whole-spine MRI excluded cord compression. It did however reveal a soft tissue mass in the pelvis anterior to the $\mathrm{S} 1$ vertebral body, just left to the midline extending into the presacral space. This was initially thought to be a lymph node mass (figure 1). Further examination of coronal and axial MR images identified an absent left kidney in the retroperitoneal space and re-evaluation of the mass raised suspicion of an ectopic pelvic kidney (figures 2 and 3). Subsequent investigation via ultrasound scan confirmed this vascular, solid organ within the pelvis abutting the urinary bladder, measuring $8.6 \mathrm{~cm}$ (figure 4). Additional assessment with urography studies is beneficial for visualising the structure and abnormalities within the urinary system.

Following neurology review, the patient had a lumbar puncture (which detected raised protein $(8 \mathrm{~g} / \mathrm{L})$ and normal white cell count in the cerebrospinal fluid) and a normal electromyogram. She was diagnosed with Guillain-Barré syndrome.

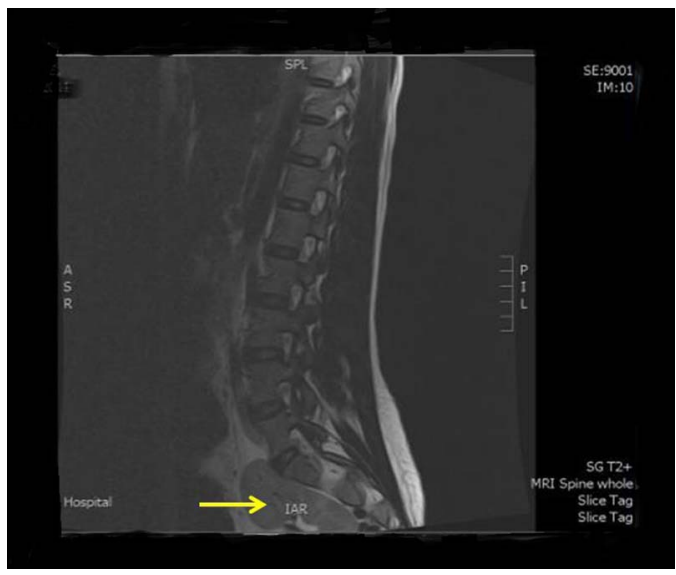

To cite: Aslam F. BMJ Case Rep Published online: [please include Day Month Year] doi:10.1136/bcr-2016218894
CrossMark

Figure 1 Sagittal view: non-contrast MRI identifying a soft tissue mass in the pelvis anterior to $\mathbf{S 1}$ vertebral body just left of the midline extended along the presacral space (arrow).

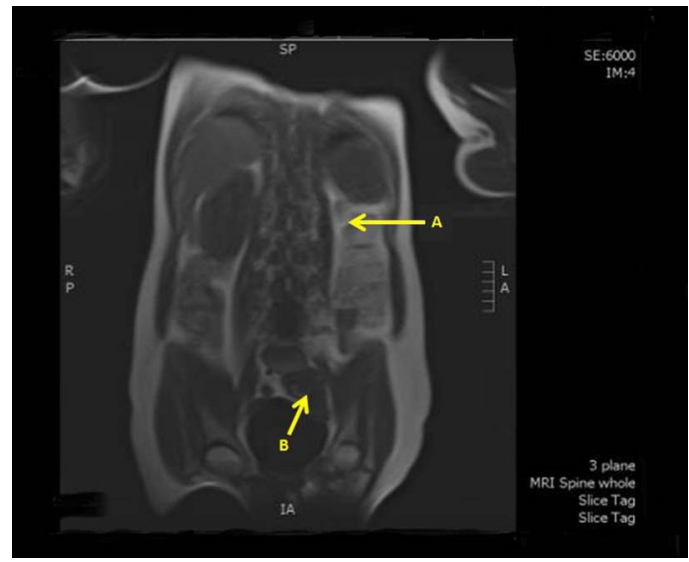

Figure 2 Coronal view: non-contrast MRI revealing an absent left kidney (A) and a pelvic mass (suspected renal ectopia) (B).

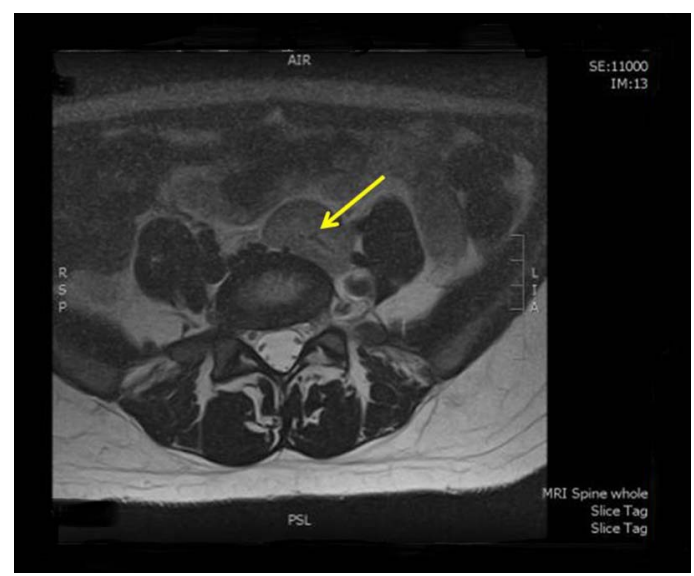

Figure 3 Axial view: non-contrast MRI revealing superior pole of the left pelvic renal ectopic (arrow).

The patient received a 5-day course of intravenous immunoglobulin along with physiotherapy and made good recovery.

Renal ectopia or ectopic kidney is a developmental anomaly resulting from failure of the solid organ to migrate to its normal location within the retroperitoneal space. Other than the pelvis, cases of iliac and thoracic kidney have also been reported in the literature. ${ }^{1}$ The majority of individuals are asymptomatic and informed of the anomaly on incidental discovery during imaging for other pathologies. Individuals can however present with a lump, abdominal or back pain and are prone to vesico-ureteric reflux and therefore infections as well as stones. ${ }^{2}$ In severe cases of anatomical or organ dysfunction, surgical intervention is required posing challenges of its own. ${ }^{3}$

In this case, the pelvic kidney was a purely coincidental find. It did not have any impact on the 


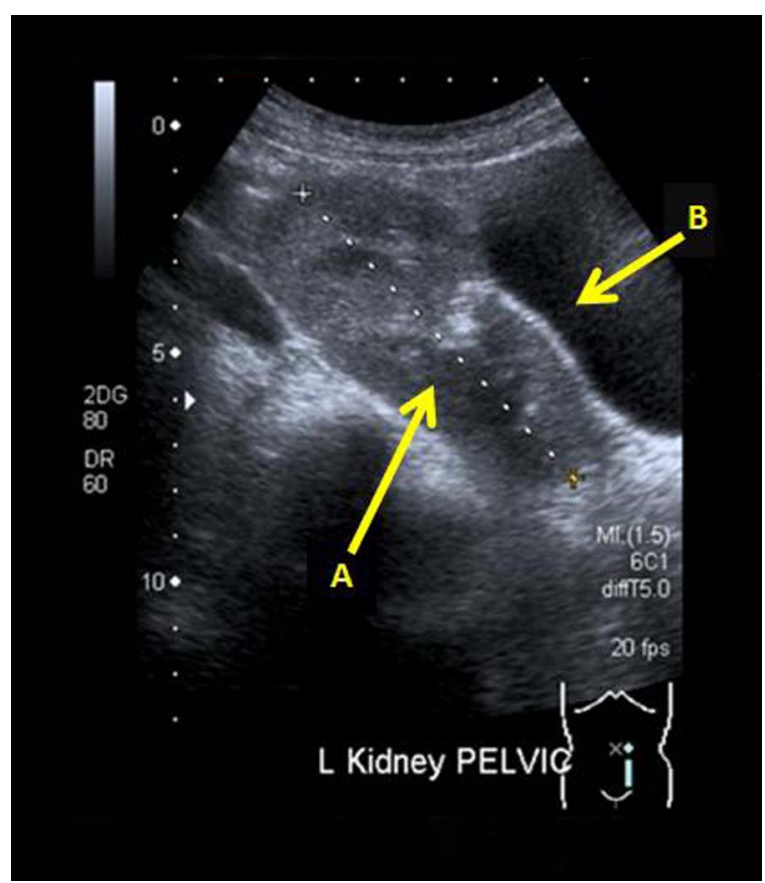

Figure 4 Lower abdominal ultrasound scan confirming a left pelvic renal ectopia measuring $8.6 \mathrm{~cm}$ in length (A), urinary bladder with normal contour (B).

treatment or subsequent recovery of her Guillain-Barré syndrome and vice versa.

Although the majority of patients with an ectopic pelvic kidney remain asymptomatic, given the history of our patient (recurrent urinary tract infections, hypertension and back pain) and the malpositioned organ, it was suspected her symptoms were related to this find. Hence, further assessment of the urinary system was warranted. Unfortunately, the patient declined further investigation, as the back pain began to resolve with analgesia, and wanted to focus on her neurorehabilitation at that time.

\section{Learning points}

- An ectopic kidney is a developmental anomaly most often detected incidentally while imaging for other pathology.

- In the majority of cases, intervention is not required unless symptomatic.

- Additional radiological investigations offer immense benefit of further exploration and, if necessary, planning for surgery.

Acknowledgements The author would like to thank Mr Shahid Siddique for his valued surgical opinion.

Competing interests None declared.

Patient consent Obtained.

Provenance and peer review Not commissioned; externally peer reviewed.

\section{REFERENCES}

1 Sakamoto K, Kojima Y, Takeda R, et al. Solitary pelvic kidney encountered during laparascopic colectomy. J Minim Access Surg 2005;1:133-5.

2 Pal DK, Jain P, Banarjee M. Bilateral pelvic kidneys: a rare anomaly. J Case Rep 2016;6:411-14.

3 Healy KA, Margules A, Kundavaram C, et al. Laparascopic pelvic nephrectomy: essential preoperative and intraoperative considerations. Can J Urol 2012;19:6299-302.

Copyright 2017 BMJ Publishing Group. All rights reserved. For permission to reuse any of this content visit http://group.bmj.com/group/rights-licensing/permissions.

BMJ Case Report Fellows may re-use this article for personal use and teaching without any further permission.

Become a Fellow of BMJ Case Reports today and you can:

- Submit as many cases as you like

- Enjoy fast sympathetic peer review and rapid publication of accepted articles

- Access all the published articles

- Re-use any of the published material for personal use and teaching without further permission

For information on Institutional Fellowships contact consortiasales@bmjgroup.com

Visit casereports.bmj.com for more articles like this and to become a Fellow 